\title{
FROM “PROBLEMATIC" FOREIGNERS TO "UNPROBLEMATIC" MUSLIMS: BOSNIANS IN THE SWISS ISLAM-DISCOURSE
}

\author{
Samuel M. Behloul, \\ Department for the Study of Religions, University of Lucerne, Switzerland
}

This article discusses the role of religion amongst the Bosnian Diaspora in Switzerland. In order to analyse this issue, it makes a distinction between the Bosnian working migrants who have lived in Switzerland since the 1970s and the Bosnian war refugees who found asylum in Switzerland from the mid-1990s onward. Despite the distinction, the issue of 'Refugees and religion' and the issue of 'Migration and religion' will overlap. The main argument of this contribution lays stress on the changing role in the meaning of religious orientation within a group of migrants. Taking the example of the Bosnian Diaspora in Switzerland, this contribution demonstrates that refugees and migrants are not simply transferring their religion as a fixed recipe for the solution of daily problems in their changed circumstances. Very often different discourses, internal and external, and new constructs influence and contribute to give religion a new meaning. While emphasis on practice of religious and ritual conventions give migrants a cultural and religious continuity, new interpretations of religious norms and directives can also produce changes and polarizations within the same ethnic group and same religious community.

Keywords: migration, religion, Islam, identity, belonging.

\section{INTRODUCTION}

Although the question of interaction between migration and religion received academic attention in the $1960 \mathrm{~s},{ }^{1}$ there was hardly any mention of the pressures of religious orientation and adjustment amongst migrants and refugees in scientific sociological studies of the 1970s and 1980s. If 'religion' at all appears in these studies, then it's only on a purely functional level, as an element that strengthens the sense of belonging and cohesion to a group. There is hardly any analysis on the understanding of religion at the individual level, as a stabilizing and senseof-self giving system for migrants as they confront and deal with internal and external challenges of migration. The self-perception and life orientation achieved through religion leads to a common identity and to group integration within an alien environment.

The American scientist of religious studies, Raymond Williams, in his study of South Asian immigrants in USA, pointed out that immigrants become more religious in their country of immigration than they were in their home country because religion gives them the identity they need to give them the feeling of self and 
connection within the group. ${ }^{2}$ Even though the influence of religion on migration is undisputed, not all migrant and refugee groups respond to religion in the same way. It is seen that Muslim immigrants make a more marked simultaneous transfer of Islam into the immigrating society because of the perceived incompatibility of Islam and Sharia with the system of values within a Western society.

The article explores the status of the Bosnian diaspora in Switzerland and demonstrates that migrants and refugees, once independent from the political and socio-cultural conditions in their home country, either do not bring anything or they bring something completely new, which does not belong to their original religious-cultural heritage, but, within the context of the diaspora is perceived as something completely personal. For the purpose of this paper, the Bosnian diaspora in Switzerland is divided into two groups: the Bosnian working migrants who have lived in Switzerland since 1970 and the Bosnian war refugees who found asylum in Switzerland from the mid 1990s. The paper examines the effect the sudden emergence of war refugees had on the religious-cultural situation of the Bosnians, who had already been in Switzerland since the 1970s. The first part of the article demonstrates how the appearance of these refugees led to a completely new internal dynamic discourse about the meaning and status of Islam among the Bosnians. The second part of the article deals with the impact of public discourse on Islam after 9/11 and its effect on the lives of the Bosnian diaspora. It shows how belonging to a religion for migrants and refugees can lead to a new way of communicating with the majority society. Hence, an originally negative connoted perception of a migrant group can be transformed into a positive perception with regard to religion. The meaning of religion for an immigrant group also depends on the co relation of socio-political conditions between home country and the country of immigration.

\section{BOSNIAN MUSLIMS IN SWITZERLAND}

A first, smaller wave of Muslim migrants came to Switzerland from Bosnia Herzegovina at the end of the 1960s, and, then, in contingents, as working migrants, from the end of the 1970s. They were mainly working males, who received a transitory working-permit as seasonal workers. In contrast to other working Muslim migrants in Switzerland, the Bosnian Muslims originated from a country which a) understood itself ideologically as an atheist state and b) in respect to religion and culture didn't bear marks of a majority Islamic orientated society, as in Turkey. Representatives of Bosnian Mosque associations in Switzerland point out to the fact that Bosnian Muslims had not been conservative believers or practising Muslims up to the split-up of the multi-national state of Yugoslavia at the beginning of the 1990s. The fact of having non-Muslims neighbours eventually led to a lot of adjustment. This not only happened in respect to eating and drinking habits (e.g. consumption of alcohol), but also in respect to the choice of partner (numerous mixed marriages with Christian partners). Up to the end of the 1980s, the Bosnians in Switzerland did not have any ethno-cultural or religious infrastructure of their own. They were similar 
to other migrants of former Yugoslavia who usually met in so-called 'Yugoslav clubs'. To express their religious needs and to participate in Friday prayers, the immigrants visited the Turkish Mosque associations, which had come into existence in Switzerland in mid-1970s. ${ }^{3}$ The Bosnians did not publicly manifest their religion till the 1980s and were, therefore, hardly noticed as Muslims by the Swiss majority society.

A Bosnian, who came to Switzerland as a working migrant at the end of the 1970 s but who only by the end of the 1980s had begun to engage himself with the creation of a religious-cultural infrastructure of the Bosnians in Switzerland, explained why this involvement with religion happened so late. He remarked: 'When I went to Switzerland I already left my religion when crossing the river Sava (river at the frontier between Bosnia Herzgovina and Croatia) back home on the Bosnian side, just as a piece of clothing. Whenever I went back home to Bosnia for a holiday, I put on this garment when crossing the bridge over the Sava on the Bosnian side'.

The first religious-cultural association of the Bosnians in Switzerland was founded in Teufental (Canton of Aargau) in 1988. This new development in the diaspora, whether one views it as a religious-cultural revival or the start of something new amongst Bosnians, had something to do with the following two factors:

a) The reunion of families, which started when it became clear to Bosnian men that they were there to stay. The fear of the families of general alienation in a foreign environment, especially of the children, prompted them to establish institutions maintain their language and culture.

b) Nearly at the same time, the decay of ideological-political and economic structures of the socialist pluralistic national state of Yugoslavia became more and more obvious. With this process, the ideological boundaries demarcating religion became fluid and people were free to reclaim their beliefs.

\section{THE WAR IN BOSNIA HERZEGOVINA}

The process of Islam as an identity-giving orientation for Bosnians was interrupted by the war in Bosnia-Herzegovina in 1992. Even though the war started with political and military aims, very quickly into the war the Muslims saw themselves the target of ethnic and religious persecution. Historic rivalries and disputes amongst the different ethnic groups surfaced and religion became a convenient tool in the hands of warring groups to create deeper divisions. All three parties to the war - Serbs, Croats and Bosnians, used religious symbols to divide and separate people and cement ethnic identity. ${ }^{4}$ Amongst Bosnian Muslims, politicians used religiously charged semantics and symbols ${ }^{5}$ to reconstruct and define their religious-ethnic identity.

It is, therefore, correct when Spela Kalcic pointes out in her article about Bosnians in Slovenia that the process of reislamization in Bosnia wasn't any spontaneous rediscovery of an Islamic consciousness, but 'primarily, an authoritarian 
process promoted by political circles that tried hard to present the war and the genocide in religious terms.'

A second important factor in the process of reislamization in Bosnia was the role played by the numerous Muslim volunteers from the Arabic-Islamic world. They were mostly supporters of the radical Wahabi Islamic ideology. These foreign fighters influenced part of the population and reislamized it in a manner and according to a tradition which was unknown to the Bosnians. Besides, they did not recognize the theological authority of the 'rijaset', the Supreme Religious Authority of Bosnian Muslims in Sarajevo. They wanted to help the Muslim population but they also acted as missionaries spreading their own religious beliefs. These were politically and spiritually radical people, who were often denounced in their own countries for their views and who found refuge in worldwide wars. They established their base specifically in Central Bosnia where they were able to propagate their brand of theology on a traumatized Muslim population victimized by persecution. That is how two trends developed among Bosnian Muslims during the war: a smaller, more radical one under the influence of the Wahabites and a moderate one under the influence of the new official Islamic community with their centre in Sarajevo. ${ }^{7}$ This development led to a polarisation among Muslims in Bosnia in respect to religious doctrines marked by a continual internal debate on 'genuine' Islam and the 'true' practice of the Islam. This debate continues even today and the Islamic community in Bosnia continues to be divided on the true interpretation of Islamic doctrines.

This internal religious debate on the future and positioning of Bosnian Islam, affected in a very emotional way, Muslims in Bosnia Herzegovina, and this ambivalence was carried by the masses of refugees who joined the Bosnian diaspora. The following section will attempt to show how the sudden impact of Muslim refugees of war from Bosnia Herzegovina affected the life of the Bosnian diaspora.

\section{BOSNIAN REFUGEES IN SWITZERLAND}

\section{Bosnians meet Bosnians}

In comparison to Tamil Hindus, who explicitly came as refugees of war and asylumseekers to Switzerland, the Muslim migrants from Bosnia had originally entered Switzerland as economic migrants. They were soon signed up by Swiss companies. When the Bosnian refugees of war arrived in Switzerland in the 1990s, they found a Bosnian diaspora already taking shape and an infra-structural integration into the local economy and into the Swiss majority society in progress.

The sudden impact of Bosnian refugees of war drastically changed the religious-cultural life of the Bosnians in Switzerland. This happened in a quantitative as well as in a qualitative way.

Firstly, as a consequence of a sudden and numerically strong influx of refugees of war, there was an intense build-up of the religious-cultural infrastructure. In 1993, there were five Bosnian Mosque Associations in Switzerland. However, from 
1993 to 2003, the foundation of 15 associations took place all over Switzerland. All the Bosnian Imams I spoke to, agreed, unanimously, that without the sudden impact of refugees of war such an intensification of religious-cultural life among Bosnians in Switzerland would, probably, never have taken place. During the years of war, for the native country of Bosnia, these associations had fulfilled essentially two tasks: they became - on one hand - the only place in the diaspora, which was in charge of a fast and efficient organisation of humanitarian aid. If, for example, on the initiative of an Imam or the general management of the Mosque, funds for aid relief for compatriots of war-stricken areas were collected, the diaspora had a guarantee that the funds would not be embezzled and that the aid would reach the target group. On the other hand, the Mosque associations became places where refugees of war, who were frightened and traumatized, were able to find not just material support but also spiritual sustenance.

Even though the creation of the first Bosnian Mosque association in Switzerland took place before the military conflict and the dissolution former Yugoslavia, the war was the catalyst that intensified such activities in the diaspora. With the arrival of Bosnian groups of refugees to the West, in $1996^{8}$ the office for the Bosnian diaspora was founded in Sarajevo at the Rijaset Supreme Authority of Religion of the Bosnians. Today, there are more than 23'000 Bosnian Muslims ${ }^{9}$ in Switzerland, organised under an umbrella organization called 'Islamska Zajednika Bosnjaka Svicarske' (Islamic Community of Bosnians in Switzerland). They have at their disposal of over 19 registered Mosque associations.

The arrival of refugees of war also had a qualitative effect on the religious life of the Bosnian diaspora. The refugees of war arrived in Switzerland under the most favourable conditions. They were received by their fellow countrymen already gainfully employed, well- established in the Swiss majority society, familiar with their host country's institutions and with the beginnings of a religiouscultural infrastructure of their own. No Swiss institutions would have had, at that time, the same resources or the sensitivity to understand and care for persecuted and traumatized refugees of war as the few Bosnian Mosque Associations that then existed. Not only did these associations looked after their material needs, they, more importantly provided the moral and spiritual support that the refugees so needed. The sudden influx of so many refugees making demands on the few Mosque associations meant a great challenge for the Bosnian working migrants. Even to cope with the basic needs of these war refugees, the existing infrastructure had either to be expanded in space or they had to start looking for new, financially viable shelters. Many of the Bosnian Imams and presidents of associations whom I spoke to, recalled the great financial pressures of those times and immense effort that was made to meet the challenge.

A far more lasting effect was achieved by the arrival of refugees in respect to religious doctrines on the Bosnian diaspora in Switzerland. The outbreak of the war in Bosnia Herzegovina caused great waves of sympathy and solidarity within the Muslim population in the Arab-Islamic world. This was not only manifested through numerous volunteers from Arabic countries who came to Bosnia in order to fight on the side of the Bosnians against the Serbs (who were militarily superior); 
during the war, numerous Arabic NGO's came into the country in order to finance and co-ordinate humanitarian projects. Along with military and humanitarian aid, individuals and groups coming mainly from the Arab world conducted religious indoctrination among the Bosnian Muslim population. Their avowed aim was to purify the religion from popular, yet 'unclean' superstitions, and to bring Bosnian Islam in conformity with the Quran and Sharia. Many Bosnians came under the direct influence of people and groups of Wahabi orientation. This development as mentioned above - led to an intensive and often polarising internal debate in Bosnia among Bosnians about the identity of the Bosnian Islam, about the roles of sexes, and on issues concerning the education of children and youth. This debate was brought about in Switzerland by streams of refugees who joined the Swiss diaspora in the 1990s. Whilst the early Bosnians in the Swiss diaspora were about to establish a religious-cultural infrastructure with a specific Bosnian Islamic character, a lot of refugees of war did not bring the local, Bosnian Islam, but a 'neutral' and 'purified' Islam to Switzerland. As explained by those I interviewed, this was already manifested by the way of greeting cultivated by the recently islamized refugees. Normally, the Bosnians greet each other with 'merhaba', which is the Osmanian form of the Arabic 'marhaban' (welcome). The refugees did not use the word 'merhaba', but 'as-salamu alaikum' (Arabic = peace be with you). They justified this step by emphasizing that this word of greeting was the only genuine way of greeting, which is obligatory for all Muslims and can be understood all over the world.

The Imam of the Bosnian Mosque association in Geneva told me of his experiences with refugees of war. As they arrived in large groups, nobody initially thought of the possible differences in respect to religious doctrines. The help offered and the solidarity shown to the traumatised women, men and children had been, at first, the unifying element within the Bosnian diaspora. This was even stronger than religion. Taking care of refugees and the organisation of humanitarian aid for the war-stricken home-country became an immense logistic challenge and also a very great financial strain for the Bosnian Mosque associations, which were then still very few.

Once the immediate response to refugee problems was over, religion, which till then had been the unifying sustaining element of the whole group, suddenly became a factor of tension. Refugees already influenced by Arab missionaries in Bosnia were keen on getting in touch with Muslims from the Arab world in Switzerland. This was especially the case in the French-speaking part of Switzerland, where the majority of Muslims of Arab origin live.

While doing field-research work amongst the Bosnian Islamic community in Yverdon, I was told by the local Imam and the president of the association that they had had considerable communication difficulties with a part of their believers, who had been originally integrated into the association as refugees of war. They had arrived from Bosnia with a different Islam and, additionally, came under the influence of conservative Arabic groups in Switzerland. When they came into the association heated debates would take place. When eating, they would refuse to use a knife and fork and they demanded that their meal should be served 
with them sitting on the floor. They justified their behaviour by the statement that the Prophet Muhammad would also not have used any cutlery and would have eaten on the floor. They objected to pictures hanging on the walls, and even more so about the TV set and asked that these offending objects be removed. In respect to their appearance, they present themselves as 'genuine' Muslims, i.e. with a full beard, white cap and a long white dress, the so-called Djalabiya. As these examples show, the refugees brought, paradoxically, a new interpretation Islam along with them and not Bosnian one.

In the Bosnian Mosque association in Emmenbrücke near Lucerne, similar internal debates gave reason to the local Imam to distribute a flyer to his believers warning them that the Wahabiyya Islam represented a danger and it was not only opposed to Bosnian Islam, but also to the Quran. In the Bosnian community of St.Gall, internal debates about the 'genuine' Islam have even led to a split in the community. There are today two Bosnian Mosque associations in the town. The word 'Vehabija' (in Bosnian Wahabit) has, in the meantime, become a swearword within the Bosnian diaspora. Regardless of professed connections or not with the Wahabiyya, just the fact that a Bosnian man wears a full beard is sufficient for him to be perceived as a Vehabija by his country-fellowmen.

\section{BOSNIAN REFUGEES AND DISCOURSE ON FOREIGNERS IN SWITZERLAND BEFORE 9/11}

Kristina Grünenberg found out in her research work on Bosnian refugees in Denmark that these refugees had a good reputation within the Danish discourse on migration when they arrived in Denmark in the mid-1990s. In contrast to other migrants and refugees from the non-European countries, these refugees were perceived as 'European refugees, light skinned, wearing European clothing' ${ }^{10}$ and, therefore, as "being like us ${ }^{11}$ characterized by the Danish society. In contrast, when Bosnian refugees of war entered Switzerland in larger numbers at about the same time, the ensuing discussions on immigration and foreigners did not look on this influx of migrants from former Yugoslavia favourably.

If one compares the development of the proportion of migrants in Switzerland between 1969 and 1995, one notices at the beginning that this proportion was subject to fluctuations. The proportion of migrants in Switzerland rose to 15\% in 1969. From the mid-1970s and up to the end of the 1980s, this proportion had slightly dropped. This proportion rose again to $19 \%$ by $1995 .{ }^{12}$ Beside the changes with reference to figures, the combination of migrants in Switzerland in respect to their origin has considerably altered. The strongest group of migrants, in respect to numbers, consisted mainly of migrants from ex-Yugoslavia in 1995, whereas in 1969, most migrants originated from Western industrial states (Italy $45,5 \%$, Germany $15,8 \%$, Spain 10,5\% and Austria). The proportion of migrants from ex-Yugoslavia amounted to $4,1 \%$ in Switzerland, it rose, however, to $21,1 \%$ by 1995 . The proportion of Italians, which was the strongest group of migrants $(45,5 \%)$ in respect to numbers in 1969 , whereas it dropped to $20,0 \%$ by $1995 .{ }^{13}$ 
Parallel to these changes in respect to figures, a change of meaning of the definition of foreigners also took place, which led to a change in attitude of the Swiss majority towards individual groups of migrants. In 1969, the negative connoted idea of foreigners referred mainly to the Italians who were perceived as the most unpopular group of migrants. Since 1995, migrants from ex-Yugoslavia and non European countries have been regarded as culturally alien and represent the most unpopular group of migrants. In contrast to Denmark, in Switzerland European origin and white skin are not decisive criteria for a positive perception but narrower distinction between West European and non West European.

When Bosnian refugees came to Switzerland in the 1990s, the connection between religion and attitude towards foreigners was not yet of importance in the public and political discourse. Accordingly, Bosnian refugees were not perceived as Muslims or even 'European Muslims' during that time, but purely just as foreigners. As a consequence of $9 / 11$ this attitude has drastically changed. Religious affiliations of a group of immigrants illicit positive or negative patterns of responses from the majority group.

\section{9/11 AND THE ISLAM-DISCOURSE IN SWITZERLAND}

\section{Bosnians meet Muslims}

Research on Islam in the West usually emphasizes, that owing to migration, the presence of Muslims in Western societies represents for Muslims a historical novelty. For the first time in the history of the Islam, Muslims have lived in large numbers in non-Islamic societies. This is, undoubtedly, correct. The fact, however, is hardly taken into account that there exists in this specific case another peculiarity. Migrants with a Muslim background in the West are also confronted with another ethno-religious 'strangeness' or difference with Muslims migrants from other political and cultural contexts. Already a few years ago, the religious sociologists, Eickelmann and Piscatori, pointed to the fact for Muslim migrants in Western Europe, that 'contrary to the conventional wisdom of western society, the encounter with Muslim 'others' has been at least as important for self-definition as the confrontation with European 'others. ${ }^{14}$

I would like to add a third peculiarity to the already two mentioned one, namely the Islam-discourse in the West in the post-9/11 era. It has had a qualitative effect on the strategies of communication and self-presentation of migrants with a Muslim background in the public sphere as well as in the relationship of Muslims to each other. This shall be portrayed with the following example of Bosnians.

\section{A TOTALISING DISCOURSE}

The question about the role of religion as an identifying characteristic of an individual or a group on one hand and the question about the social-political relevance of the appearance of religions in the public arena on the other hand, has had increased attention since $11^{\text {th }}$ September 2001. However, religion and the 
belonging to a religion after $9 / 11$ has become an indicator for positive or negative social acceptance for individuals and groups. In public perception, migrants of different societies, but with an Islamic background, are being reduced to a single factor of a foreign non-European religion in comparison to other migrating groups. Islam is, thereby, perceived within a norm-giving direction for the individual and the group and, is, accordingly, being used as the only frame of reference for their ability of civil behaviour and mainstream integration. This finally leads to the impression that one only has to consult the Quran in order to find out the degree of reasonableness of 'the' Islam and 'the' Muslims within a democratic and legally secular society.

Although the history of the Islamic religion within the European history of religion does not represent a new phenomenon and, therefore, the perception and the analysis of Islam is integral to a continuity of European history of politics, culture and religion, ${ }^{15}$ a new way of communication with and perception of Islam in Switzerland and West Europe has been introduced as a consequence of the 9/11 events. The discourse on Islam in the post-9/11 era is a debate with the participation of not just certain actors of society, e.g. politics or academic institutions - but it is a 'total' discourse with the inclusion of all segments of society. ${ }^{16}$ It covers immigration and integration; inter-religious dialogue projects and educational projects with the aim of promoting the inter-cultural competences; discourse about religious education of children, about the regulations of relationship between religion and state, about freedom of art, about the religious-cultural inheritance of Europe; and, last but not least, the discourse about the architectural formation of the public sphere. All these issues have been brought under public scrutiny, and are linked with the post-9/11 era discourse on Islam. These discussions have a strong normative connotation and circle around the question about compatibility of 'the' Islam with legally secular and liberal values of Western societies.

The Islam-discourse in Switzerland has not only influenced and dominated various socio-political debates and events, but has also had had an impact on Islamic issues within a relatively short period of time. In 2003, the cantonal referendum about public-legal recognition of non-Christian religious communities in the Canton of Zurich was reduced to an Islamic issue on the emerging danger of reducing tax support to Quranic schools. The referendum on an easier access to naturalisation of migrants of the $2^{\text {nd }}$ and $3^{\text {rd }}$ generation in Switzerland in 2004 became a debate about the Islam and the Muslims. The opponents of the ballot pointed out to the danger that - in case of a positive issue of the ballot - the Muslims would augment their numbers in the Swiss population by $70 \%$ by 2040 . The 'Islamisation' of this debate contributed in a decisive way to the refusal of the initiative. The question of the maintenance of religious peace in Switzerland has been discussed by the Christian Democratic Party (CVP) with the example of 'Muslims in Switzerland' in the media and, as a consequence, a so-designated 'Muslim paper' has been issued. ${ }^{17}$

Affiliation to a religion has taken the shape of a control apparatus. Today, to be acceptable to a host society, a Muslim needs to constantly justify himself, distance himself from the abuses of his religion and publicly profess his affiliation 
to and respect for human rights, for democracy, for a secular and liberal legal order and for the equality of sexes. The normative observation and expectation of the society of majority is probably most accurately shown when migrants with an Islamic background - for example - are expected to distance themselves from the terror attacks of the Islamists. They are expected to take position unequivocally as a 'Muslim collective'. It is, therefore, no coincidence that semantics of peace and condemnation of Islamic terrorism through the internet have become distinctive marks for the self-preservation of Muslim umbrella associations in Switzerland.

\section{FROM 'PROBLEMATIC’ FOREIGNERS TO ‘UNPROBLEMATIC’ MUSLIMS}

The continuing stress of Islam after 9/11 as the absolute opposite of the genuine Western values caused the Muslims in Switzerland to take a new approach to the host society. Nearly all hitherto Muslims' contacts focused on representatives of the local government for the purpose of getting permission to set up their own infrastructure. However, recently, the host society as a whole became more of a new target group.

By the time of the terror attacks in London on $7^{\text {th }}$ July 2005, Islam became a kind of 'statement religion' in Switzerland. Under public pressure, representatives of Muslim groups felt obliged to deliver condemning statements against the Islamic terrorism and to distance themselves, in the name of the Islam, against any form and use of violence.

The normative discourse on Islam is obliged to take into account religious, cultural and any other perceptions of Swiss society. This has led to interesting debates among Muslim migrants about the compatibility of the Islam with the Western system of values. These developments are accompanied by dynamic and normative internal discourses among Muslims. For some groups - this being especially relevant for Bosnians - these discussions have led to partly contradictory forms of normative 'Islamic' proximity to the West on an ethno-religious basis as well as to an 'Islamic' defined normative drawing of line towards the 'others' of a Muslim background.

Some examples may portray this development. Bosnian Muslims, for instance, are fencing themselves off from the Turkish or Arab Muslims, stressing on a shared European culture with the West. I often heard this line of argument in conversations with Bosnian Imams or with ordinary people meeting in their ethno-religious associations. I noticed that their arguments aimed exactly at those points that served the host society best and prevented the stigmatising of Islam as a pure contrast to Western values, such as the social status of women, the strict dress regulations for women, enforced marriages etc. Bosnian Muslims also tended to dissociate themselves from other ethnic associations by presenting theirs as more liberal and emancipated. They pointed out that in their associations when a religious-cultural event takes place, women are not obliged to wear a headscarf and they are free to speak and shake hands with whom they choose. During a visit to the Iftar-meal in a Bosnian association, the Imam, who had come as a refugee of war to Switzerland, emphasised with pride, that his 19 year old daughter wouldn't 
wear a scarf, and stressed that such a thing would be unthinkable in an Arabic or Turkish centre. His wife, who spoke better German than he did, was in charge of a guided visit of the Mosque for the Swiss visitors. In this context he made the following remark to me:

"Have you ever seen a woman in the Albanian or Turkish association? They all are locking in their women and daughters at home. You'll hardly see a woman at their associations, especially when they are expecting a visit from non-Muslims."

During my visit to another Bosnian association, the president there told me that he didn't like it if Arab or Pakistani Muslims with long beards and in traditional dress came to the Friday prayer in his association. In this way they would harm the European and secular image of Bosnian Islam and could expose the association to the suspicion of the local population as a meeting place of Islamists. In fact, it seemed that the Bosnian associations were so concerned about appearance that they almost obliged the men who participated to shave.

It is pointed out in social-scientific studies about migration, that, migrants, independent from belonging to a religion or a cultural background, are likely to be affected from being excluded from the social systems of their country of residence. ${ }^{18}$ A non-Christian group of migrants' or refugees' reaction to exclusion depends on the difference in values between their country of origin and that of migration. In Switzerland, this question becomes even more interesting considering the fact that the group of migrants, which has been carrying the stigma of the most disadvanteged group of foreigners since the 1990s, represents the majority, 58\% (being verified statistically), or over 320'000 Muslims living in Switzerland. A tendency observed among this group of refugees and migrants - particularly the Bosnians - is to portray their religiosity as mild, private and personal, in an attempt to shaking off the stereotypes. By presenting themselves as moderates and assimilated European Muslims, Bosnians hope to expand their channels of communication with the Swiss and promote better inclusion in their social systems.

If one considers that the image of Muslims of former Yugoslavia (Albanians and Bosnians) is becoming more moderate and acceptable in the Swiss public perception, then the point of a change in social attitudes of receiving them as 'unproblematic' Muslims rather than 'problematic' foreigners is not far. On the occasion of my numerous public lectures on the topic of Islam and Muslims in Switzerland, I am often asked to concentrate more on the problems and issues of Muslims of Arab and Turkish backgrounds rather on Balkan Muslims, who are, in any case, unproblematic. The specific discourse on Islam in the post-9/11 era has led to new dynamics of identifying with the religion of Islam among Bosnian migrants, be they refugees or working migrants.

\section{CONCLUSION}

The discussion within this article has shown that the question evaluating the importance of religion in the life of refugees or migrants cannot be sufficiently grasped with just a standardized approach in analysis. 
The meaning of religion for a group of refugees depends on the socio-political conditions in the native country on one side and on the conditions of the country of immigration on the other side.

The examples of Bosnians in the Swiss diaspora show us that refugees do not necessarily bring religion as practiced in their native country into the country of immigration. However, various socio-political conditions, as well as internal and external discourses, often influence the importance of religion for a group. Belonging to a religion can lead to preservation of a religious-cultural continuity in the sense of the maintenance of religious and ritual conventions. However, it can also produce changes and polarisations in respect to the interpretation of religious norms and directives within one and the same group.

The article has shown that normally negative connotations of belonging to a religion can - under certain conditions - become a medium of communication with the society of majority. It can even become a reason for a positively connoted perception of a foreign group. Religion should not be reduced to the factors of belief and spirituality. It can, especially, in view of Bosnians, be shown that the belonging to a religion may become an identity-marker in variable, even contrary ways - and this not only on a religious, but also on an ethnic level. Whereas the belonging to Islam in Bosnia serves as a clear ethnic characteristic of distinction between the non-Islamic population (Serbs and Croats), the same belonging to the religion of the Islam became the characteristic of distinction, with reference to the value towards the other groups of Muslim migrants in the diaspora on the one side, and to the factor of an identification, with reference to the values within the Swiss society on the other side. This example shows that Muslim migrants, who are generally perceived in the West in the religious-cultural and normative sense as an anti-thesis of Western societies, need not accept their diaspora situation as something strange. This is shown by the "ethno-religious" strategies of acquisition and de-limitation based on norms by the Bosnians in Switzerland.

Socio-cultural and political conditions play an important role with regard to the definition of the role which is attributed to belonging to a religion by an individual or a group. This is applicable both for the country of origin as well as the diaspora. The totalising discourse on the Islam and the presence of other Muslims can represent a far greater challenge for a certain group of migrants and refugees with an Islamic background than the fact that they live in democratic and legal-secular societies and have - as a consequence - to find a way of their own.

Refugees and migrants do not simply transfer religion as a fixed recipe for the solution of daily problems. However, very often different discourses - internal and external - have an influence and contribute to the construction of the meaning of religion again and again. 


\section{References}

Baumann, Christoph Peter, Jäggi Christian J, Muslime unter uns. Islam in der Schweiz, (Luzern/Stuttgart: Rex Verlag, 1991).

Behloul, Samuel M., 'The Society is watching You! Islam-Diskurs in der Schweiz und die Konstruktion einer Religion des Bürgers', Theologische Berichte, forthcoming.

Breton, Raymond, 'Institutional Completeness of Ethnic Communities and the Personal Relations of Immigrants', American Journal of Sociology, Vol. 70 (1964) p. 193-205.

Bogdan Denic, Etnicki nacionalizam. Tragicna smrt Jugoslavije (Beograd 1999).

Eickelmann, Dale F., Piscatori, James, Muslim travellers: pilgrimage, migration, and the religious imagination, (Los Angeles: university of California Press, 1990),

EKA (Eidgenössische Kommission für Ausländerfragen) (ed.), Muslime in der Schweiz. Identitätsprofile, Erwartungen und Einstellungen. Eine Studie der Forschungsgruppe "Islam in der Schweiz» (GRIS: Bern 2005).

Grünenberg, Kristina, 'Constructing "Sameness" and "Difference": Bosnian Diasporic Expereinces in a Danish Context', Balkanologie. Revue d’études pluridisciplinaires, Vol. IX, Nr. 1-2 (December 2005).

Hagemann, Ludwig, Christentum contra Islam. Eine Geschichte gescheiterter Beziehungen, (Darmstadt: Primus Verlag 1998).

Hoffmann-Nowotny, Hans-Joachim, ed., Das Fremde in der Schweiz, Ergebnisse sozioligischer Forschung, (Zürich: Seismo, 2001).

Johnston, Douglas/Eastvold, Jonathan (2002) Religion in the Bosnian Conflict. In: Coward, Harold/Smith, Gordon (eds.) Religion and Peacebuilding. New York.

Kuschel, Karl-Josef, Vom Streit zum Wettstreit der Religionen. Lessing und die Herausforderung des Islam, (Düsseldorf: Patmos 1999).

Mol, Hans, Churches of Immigrants. A Sociological Study of the Mutual Effect of Religion and Immigrant Adjustment, (Den Haag: Research Group for European Migration Problem Bulletin, Supplemnt 5, 1961).

Stichweh, Rudolf, Inklusion und Exklusion. Studien zur Gesellschaftstheorie, (Bielefeldt: transcript 2005).

Waardenburg, Jacques, Muslims and Others. Relations in Context, (Berlin-New York: Walter de Gruyter 2003)

Williams, Raymond Brady, Religions of immigrants from India and Pakistan: new threads in the American tapestry, (Cambridge: Cambridge University Press, 1988).

\section{Notes}

1 See for exemple Hans, Mol, Churches of Immigrants. A Sociological Study of the Mutual Effect of Religion and Immigrant Adjustment, (Den Haag: Research Group for European Migration Problem Bulletin, Supplemnt 5 , 1961) and Raymond, Breton, 'Institutional Completeness of Ethnic Communities and the Personal Relations of Immigrants', American Journal of Sociology, Vol. 70 (1964) p. 193-205.

2 See Raymond Brady Williams, Religions of immigrants from India and Pakistan: new threads in the American tapestry, (Cambridge: Cambridge University Press, 1988), p. 11.

3 See Christoph Peter Baumann, Christian J. Jäggi, Muslime unter uns. Islam in der Schweiz, (Luzern/Stuttgart: Rex Verlag, 1991), p. 69-87.

4 Bogdan Denic, Etnicki nacionalizam. Tragicna smrt Jugoslavije (Beograd 1999), p. 30.

5 Re-construction of a religious-ethnic identity of their own arose in front of the background of war - thus naming herewith some examples - printed media with the names such as 'Preporod' (Renaissance), 'Glas Islama' (Voice of Islam), 'Novi Horizonti' (New Horizons. Islamic symbols such as the crescent, verses of the Quran on headbands of the soldiers also found access to the Bosniak Army.

6 Spela Kalcic, 'Changing Contexts and Re-definitions of Identity among Bosniaks in Slovenia', Balkanologie. Revue d'études pluridisciplinaires, Vol. IX, Nr. 1-2 (December 2005), p. 155.

7 See Johnston, Douglas/Eastvold, Jonathan (2002) Religion in the Bosnian Conflict. In: Coward, Harold/ Smith, Gordon (eds.) Religion and Peacebuilding. New York.

8 The office is in a close contact with over 200 religious-cultural associations of Bosniak Muslims (in Bosniak: Dzemat, i.e. organisation, association) in Europe, USA, Canada and Australia and is responsible for the functioning of religious life in the diaspora.

9 See EKA (Eidgenössische Kommission für Ausländerfragen) (ed.), Muslime in der Schweiz. Identitätsprofile, Erwartungen und Einstellungen. Eine Studie der Forschungsgruppe «Islam in der Schweiz» (GRIS: Bern 2005), p. 14.

10 Kristina Grünenberg, 'Constructing "Sameness" and "Difference”: Bosnian Diasporic Expereinces in a Danish Context', Balkanologie. Revue d'études pluridisciplinaires, Vol. IX, Nr. 1-2 (December 2005), p. 180.

11 Ibid., p. 176.

12 See Hans-Joachim Hoffmann-Nowotny, ed., Das Fremde in der Schweiz, Ergebnisse sozioligischer Forschung, (Zürich: Seismo, 2001), p. 33-75.

13 See ibid., p. 37. 
14 Dale F. Eickelmann, James Piscatori, Muslim travellers: pilgrimage, migration, and the religious imagination, (Los Angeles: university of California Press, 1990), p. xv.

15 See for example Jacques Waardenburg, Muslims and Others. Relations in Context, (Berlin-New York: Walter de Gruyter 2003); Karl-Josef Kuschel, Vom Streit zum Wettstreit der Religionen. Lessing und die Herausforderung des Islam, (Düsseldorf: Patmos 1999); Ludwig Hagemann, Christentum contra Islam. Eine Geschichte gescheiterter Beziehungen, (Darmstadt: Primus Verlag 1998).

16 See Samuel M. Behloul, 'The Society is watching You! Islam-Diskurs in der Schweiz und die Konstruktion einer Religion des Bürgers', Theologische Berichte, forthcoming.

17 Identität und Religionsfreiheit - am Beispiel der Musliminnen und Muslime in der Schweiz. Vernehmlassungsvorlage zuhanden des Parteivorstands, der Kantonalparteien und der CVP-Staats- und Regierungsräte, 2006.

18 See for example Rudolf Stichweh, Inklusion und Exklusion. Studien zur Gesellschaftstheorie, (Bielefeldt: transcript 2005). 